Journal of

Women's Health and Gynecology

\title{
Survival Analysis of Women with Triple Negative Breast Cancer Using EMR- Linked Cancer Registry Data in Florida
}

\author{
Hong Xiao ${ }^{1, *}$, Askal Ayalew Ali ${ }^{2}$, Fei Tan ${ }^{3}$, Georges Adunlin ${ }^{4}$, Youjie Huang
}

${ }^{1}$ Pharmaceutical Outcomes \& Policy,,College of Pharmacy, HPNP 3338, University of Florida 1225 Center Drive, Gainesville, FL 32610

${ }^{2}$ Economic, Social \& Administrative Pharmacy, College of Pharmacy and Pharmaceutical Sciences, Florida A\&M University, Tallahassee, FL, 200 Dyson Pharmacy Bldg, 1520 Martin Luther King Jr. Blvd Tallahassee, Florida 32307

${ }^{3}$ Mathematical Sciences, Purdue School of Science, Indiana University-Purdue University Indianapolis, Indianapo-

lis, IN, 402 N. Blackford, LD 270, Indianapolis IN 46202

${ }^{4}$ Cancer Prevention and Control Fellow, Virginia Commonwealth University School of Medicine, PO Box 980149, Richmond, VA 23298

${ }^{5}$ Florida Department of Health (Retired)

${ }^{\star}$ Corresponding author: Hong Xiao, Pharmaceutical Outcomes \& Policy, College of Pharmacy, HPNP 3338, University of Florida, 1225 Center Drive, Gainesville, FL 32610, Office Phone: 352-273-6711, Fax: 352-273-6270; Email: HXiao18@cop.ufl.edu

Received Date: September 10, 2016; Accepted Date: September 25, 2016; Published Date: September 28, 2016

Citation: Hong Xiao, et al. (2016) Survival Analysis of Women with Triple Negative Breast Cancer Using EMR-Linked Cancer Registry Data in Florida. J Womens Health Gyn 1: 1-10.

\footnotetext{
Abstract

Background: Triple negative breast cancer (TNBC) is an aggressive tumor phenotype which has limited therapeutic options. Epidemiological studies suggested a number of risk factors that are associated with the prognosis of TNBC. Survival difference exists among patients diagnosed with TNBC after adjusting these risk factors. This study aims to investigate the survival of women with triple negative phenotype breast cancer (BC).

Methods: Electronic medical records from a network of 9 hospitals were linked to female BC patients diagnosed between 2007 and 2010 in Florida. Cox proportional hazards model was used.

Results: Two-year survival of the BC patients was $95.1 \%$. Median follow-up time for those who died due to BC was 569 days. Survival functions between Blacks and non-Blacks were significantly different over time $(\mathrm{p}<0.0001)$. Survival probability among Blacks was lower than that of non-Blacks. Hazard of BC death among patients with TNBC and patients with unknown status were 4.34 and 2.35 times that of non-TNBC patients, respectively. Death rate among Blacks was 1.6 times that of non-Blacks. Other factors associated with increased hazard were: unmarried, Medicare recipients, diagnosis of regional stage or unknown stage, poorly or un-differentiated tumor, larger tumor size, and more positive nodes detected. Immediately after diagnosis, distant stage and more comorbidity conditions were associated with an elevated risk, and more lymph nodes examined was associated with reduced risk of $\mathrm{BC}$ death. However these effects gradually attenuated over time.

Conclusions: Women with triple negative BC have the worst survival outcome. This study highlights the importance of improvement of care for patients with TNBC biomarkers.

Keywords: Breast cancer; Triple negative; Survival; Electronic medical records
} 


\section{Introduction}

Breast cancer $(\mathrm{BC})$ is the most common malignancy affecting women and the second common cause of cancerrelated death among women in the United States [1]. It is estimated that 246,660 new cases of invasive breast cancer will be diagnosed in women, and 40,450 women will die from this disease in the United States in 2016 [1]. Breast cancer disproportionally affects minority $\mathrm{racial} / \mathrm{ethnic}$ and economically disadvantaged groups [1]. Black women are more likely to be diagnosed at a later stage and to experience higher breast cancer mortality compared with White women [1]. Breast cancer is a heterogeneous disease, comprising multiple entities associated with distinctive histological and biological features. Breast cancers that have estrogen receptors are often referred to as ER-positive (or ER+) cancers while those containing progesterone receptors are called $\mathrm{PR}$-positive (or $\mathrm{PR}+$ ) cancers.

Triple-negative breast cancer (TNBC) is a subtype of breast cancer that is estrogen receptor negative (ER-), progesterone receptor negative (PR-), and human epidermal growth factor receptor 2 (HER2) negative. TNBC accounts for $12 \%$ of overall breast cancer [1]. TNBC carries a particularly unfavorable prognosis and has limited therapeutic options [2,3]. Black women are more likely to be diagnosed with TNBC, compared to women of other ethnic groups $[4,5]$ and coincidentally they have the worse survival from $\mathrm{BC}$ among all women with $\mathrm{BC}$ [5]. However, it is unclear whether triple-negative phenotype is a significant contributing factor to the survival of Black women [6-8]. It is also unknown whether survival differences persist after adjusting for disparities in comorbidity, access to treatment, disease and socioeconomic status.

Population-based cancer registry data are widely used for breast cancer survival analysis. However, most of cancer registry data, if not all, do not contain tumor phenotype of individual patients and/or do not have a long follow-up period. Therefore individual based long-term breast cancer outcomes research is hindered. To overcome this data limitation, we linked BC phenotype information in the hospital electronic medical records with the Florida cancer registry data through a partnership between the Florida Department of Health, the Florida Cancer Data System (FCDS) and a large Florida hospital network [9]. The linked dataset allows a comprehensive analysis of BC survival in relation to individual women's tumor phenotype.

\section{Methods}

\section{Study population and data sources}

Women who were diagnosed and/or treated in any of the 9 hospitals of the hospital network were included in this study. The hospital network's electronic medical records (EMRs) contain detailed patient medical and demographic information. Invasive breast cancer patients were identified among patients whose principal diagnosis or a secondary diagnosis code was International Classification of Diseases (ICD-9-CM) code between 174.0 and 174.9. The EMR records of invasive breast cancer patients were then linked to the state cancer registry data using unique patient identifiers.
Study subjects were restricted to female breast cancer patients with diagnosis and/or treatment within the partner hospital system between 2007 and 2010. This study was approved by the Florida Department of Health Institutional Review Board (\#H11163).

\section{Statistical analyses}

This study focused on time from diagnosis of breast cancer to death due to breast cancer. Patients who died due to other reasons during the study period were censored at death, and patients who did not die were censored at end of study. Sample mean and sample proportion were utilized to summarize patient characteristics. Associations between categorical variables were tested using $\chi^{2}$ tests, and group means were compared using T-tests. The Kaplan-Meier method was used to estimate survival probabilities and create survival curves. The Log-rank test was applied to compare survival probability over time between Black and non-Black patients. Multivariate Cox proportional hazards model was used to assess effects of factors in multivariable setting. While total comorbidity and triple negative status were kept in model, forward stepwise model selection procedure was adopted to detect other variables that were associated with breast cancer survival. Statistical analyses for this study were performed using SAS/STAT ${ }^{\circledR}$ software, Version 9.3 of the SAS System for Windows (Cary, North Carolina).

\section{Results}

Patient characteristics by race are summarized in Table 1. Among all patients, $6.87 \%$ died from breast cancer and $4.98 \%$ died from other causes during study period. The majority of the patients were age of over 50 years at diagnosis (75.62\%). Most of the patients were White (89.16\%), non-Hispanic (93.30\%), while Blacks made up $9.07 \%$ of the study patients. Distribution of socioeconomic status shows that the majority of patients came from areas where $10 \%-20 \%$ population living in poverty (34.19\%) or areas where $5 \%-10 \%$ of population living in poverty $(30.31 \%)$, while $14.15 \%$ came from areas where over $20 \%$ of population living in poverty and $19.17 \%$ were from areas where less than $5 \%$ of population living in poverty. About half of the patients were married (51.40\%), and $46.40 \%$ of patients were unmarried. Over half of patients (52.58\%) had medical insurance other than Medicaid or Medicare. Among the study population, $35.92 \%$ patients were Medicare recipients, $7.11 \%$ were Medicaid beneficiaries, and $2.61 \%$ without an insurance. On average, each patient had one comorbidity.

Race was associated with all patient characteristic variables. Specifically, percentage of Blacks among those who died from breast cancer was the highest $(21.45 \%)$, while the percentages among people who were alive by end of study and people who died from other causes during study period were around the same $(8.16 \%$ and $8.10 \%$, respectively). The proportion of Black patients diagnosed at age 50 or below was higher (12.88\%) than that among patients diagnosed at age of over 50 (7.84\%). Blacks counted for $9.54 \%$ of non-Hispanic patients, while only $2.86 \%$ of Hispanic patients. 
Table 1: Patient characteristics and relation with race $(\mathrm{N}=4,220)$

\begin{tabular}{|c|c|c|c|c|c|}
\hline Variable & & Percentage & Non-Black ${ }^{*}$ & Black $^{*}$ & $\mathrm{p}$-value \\
\hline \multirow[t]{3}{*}{ Vital status } & Alive & 88.15 & 91.84 & 8.16 & $<.0001$ \\
\hline & $\begin{array}{l}\text { Dead due to breast } \\
\text { cancer }\end{array}$ & 6.87 & 78.55 & 21.45 & \\
\hline & $\begin{array}{l}\text { Dead due to other } \\
\text { reasons }\end{array}$ & 4.98 & 91.90 & 8.10 & \\
\hline \multirow[t]{2}{*}{ Age at dx } & Age at $d x<=50$ & 24.38 & 87.12 & 12.88 & $<.0001$ \\
\hline & Age at dx $>50$ & 75.62 & 92.16 & 7.84 & \\
\hline \multirow[t]{3}{*}{ Race } & White & 89.16 & & & \\
\hline & Black & 9.07 & & & \\
\hline & Other & 1.76 & & & \\
\hline \multirow[t]{2}{*}{ Hispanic } & No & 93.30 & 90.46 & 9.54 & 0.0002 \\
\hline & Yes & 6.70 & 97.14 & 2.86 & \\
\hline \multirow[t]{5}{*}{$\begin{array}{l}\text { Social economic } \\
\text { status }\end{array}$} & $\begin{array}{l}>20 \% \text { living below } \\
\text { poverty line }\end{array}$ & 14.15 & 68.30 & 31.70 & $<.0001$ \\
\hline & $\begin{array}{l}\text { Between } 10 \% \text { and } \\
<20 \% \text { of popula- } \\
\text { tion living in pov- } \\
\text { erty }\end{array}$ & 34.19 & 91.45 & 8.55 & \\
\hline & $\begin{array}{l}\text { Between } 5 \% \text { and } \\
<10 \% \text { of popula- } \\
\text { tion living in pov- } \\
\text { erty }\end{array}$ & 30.31 & 96.62 & 3.38 & \\
\hline & $\begin{array}{l}<5 \% \text { of population } \\
\text { living in poverty }\end{array}$ & 19.17 & 96.90 & 3.10 & \\
\hline & Unknown & 2.18 & 97.80 & 2.20 & \\
\hline \multirow[t]{3}{*}{ Married } & Unmarried & 46.40 & 87.93 & 12.07 & $<.0001$ \\
\hline & Married & 51.40 & 93.76 & 6.24 & \\
\hline & Unknown & 2.20 & 87.18 & 12.82 & \\
\hline \multirow[t]{5}{*}{ Insurance } & Not insured & 2.61 & 88.99 & 11.01 & $<.0001$ \\
\hline & Medicaid & 7.11 & 76.92 & 23.08 & \\
\hline & Medicare & 35.92 & 94.17 & 5.83 & \\
\hline & Other insurance & 52.58 & 90.48 & 9.52 & \\
\hline & Unknown & 1.78 & 97.33 & 2.67 & \\
\hline Total comorbidity & & $0.99(1.45)$ & $0.96(1.41)$ & $1.31(1.80)$ & 0.0003 \\
\hline
\end{tabular}

* row $\%$ or mean (std. dev.)

The proportion of Blacks was much higher among patients coming from areas where over $20 \%$ of population lived in poverty $(31.70 \%)$, from areas where $10 \%-20 \%$ of population lived in poverty $(8.55 \%)$ than among patients living in affluent areas where $5 \%-10 \%$ of population lived in poverty $(3.38 \%)$ or areas where less than $5 \%$ of population lived in poverty (3.10\%). The percentage of Blacks was lower among married patients $(6.24 \%)$, than among unmarried patients $(12.07 \%)$ and among patients with unknown marital status (12.82\%). Among patients with a health insurance, the proportion of Blacks was the highest among Medicaid beneficiaries
(23.08\%), followed among patients without insurance (11.01\%), among patients with other insurance (9.52\%) and Medicare recipients (5.83\%). On average, a Black patient had more comorbidity conditions (1.31) than a non-Black patient (0.96). Two-year survival was estimated to be $95.1 \%$. The median follow-up time for those who died due to breast cancer was 569 days. Table 2 presents the distributions of tumor characteristic and treatment by race. 
Table 2: Tumor characteristics, treatment, and relation with race $(\mathrm{N}=4,220)$

\begin{tabular}{|c|c|c|c|c|c|}
\hline Variable & & Percentage & Non-Black ${ }^{*}$ & Black $^{*}$ & $\mathrm{p}$-value \\
\hline \multirow[t]{3}{*}{ ER } & - & 19.55 & 85.52 & 14.48 & $<.0001$ \\
\hline & + & 72.87 & 92.28 & 7.72 & \\
\hline & Unknown & 7.58 & 91.85 & 8.15 & \\
\hline \multirow[t]{3}{*}{ PR } & - & 34.27 & 87.98 & 12.02 & $<.0001$ \\
\hline & + & 57.89 & 92.67 & 7.33 & \\
\hline & Unknown & 7.84 & 90.91 & 9.09 & \\
\hline \multirow[t]{3}{*}{ HER2 } & - & 17.94 & 89.23 & 10.77 & 0.2082 \\
\hline & + & 4.91 & 91.26 & 8.74 & \\
\hline & Unknown & 77.16 & 91.29 & 8.71 & \\
\hline \multirow[t]{3}{*}{ Triple Negative } & No & 74.91 & 92.24 & 7.76 & $<.0001$ \\
\hline & Yes & 2.61 & 72.22 & 27.78 & \\
\hline & Unknown & 22.49 & 88.71 & 11.29 & \\
\hline \multirow[t]{4}{*}{ Breast surgery } & No surgery & 1.49 & 88.89 & 11.11 & 0.0009 \\
\hline & Mastectomy & 38.70 & 89.78 & 10.22 & \\
\hline & Other surgery & 51.68 & 92.49 & 7.51 & \\
\hline & Unknown & 8.13 & 86.76 & 13.24 & \\
\hline \multirow[t]{3}{*}{ Hormone } & No & 78.20 & 90.71 & 9.29 & 0.2581 \\
\hline & Yes & 20.78 & 91.41 & 8.59 & \\
\hline & Unknown & 1.02 & 97.62 & 2.38 & \\
\hline \multirow[t]{3}{*}{ Radiation } & No & 68.27 & 91.11 & 8.89 & 0.6310 \\
\hline & Yes & 31.02 & 90.62 & 9.38 & \\
\hline & Unknown & 0.71 & 86.67 & 13.33 & \\
\hline \multirow[t]{3}{*}{ Chemo } & No & 62.04 & 92.78 & 7.22 & $<.0001$ \\
\hline & Yes & 35.38 & 87.42 & 12.58 & \\
\hline & Unknown & 2.58 & 94.50 & 5.50 & \\
\hline \multirow[t]{4}{*}{ Stage } & Localized & 62.42 & 92.86 & 7.14 & $<.0001$ \\
\hline & Regional & 28.63 & 88.69 & 11.31 & \\
\hline & Distant & 4.93 & 81.16 & 18.84 & \\
\hline & $\begin{array}{l}\text { Unknown/un- } \\
\text { staged }\end{array}$ & 4.03 & 88.82 & 11.18 & \\
\hline \multirow[t]{3}{*}{ Grade } & Well-differentiated & 20.45 & 95.33 & 4.67 & $<.0001$ \\
\hline & $\begin{array}{l}\text { Moderately-differ- } \\
\text { entiated }\end{array}$ & 38.51 & 92.97 & 7.03 & \\
\hline & $\begin{array}{l}\text { Poorly- or un-dif- } \\
\text { ferentiated }\end{array}$ & 41.04 & 86.82 & 13.18 & \\
\hline \multirow[t]{3}{*}{ Histology } & Ductal & 83.29 & 90.79 & 9.21 & 0.0094 \\
\hline & Lobular & 10.69 & 94.00 & 6.00 & \\
\hline & Other & 6.02 & 87.25 & 12.75 & \\
\hline Tumor Size (mm) & & $21.98(19.93)$ & $21.37(19.42)$ & $28.34(23.80)$ & $<.0001$ \\
\hline $\begin{array}{l}\text { Number of positive } \\
\text { nodes examined }\end{array}$ & & $1.14(2.97)$ & $1.07(2.88)$ & $1.77(3.77)$ & 0.0004 \\
\hline $\begin{array}{l}\text { Total number of } \\
\text { nodes examined }\end{array}$ & & $6.11(7.36)$ & $5.97(7.28)$ & $7.50(8.06)$ & 0.0004 \\
\hline
\end{tabular}

${ }^{\star}$ row $\%$ or mean (std. dev.) 
The majority of patients had ER+ results (72.87\%), PR+ results (57.89\%), unknown HER2 status (77.16\%), and were not diagnosed with triple negative (74.91\%). Most patients had some type of surgery where $38.70 \%$ had mastectomy and $51.68 \%$ had other surgery. Most patients were not given hormone therapy $(78.20 \%)$, or radiation therapy $(68.27 \%)$, or chemotherapy $(62.04 \%)$. A large proportion of patients had localized diagnosis stage $(62.42 \%)$, followed by regional diagnosis stage $(28.63 \%)$. Only $4.93 \%$ of patients who were diagnosed with distant stage. In the study sample, $41.04 \%$ of patients had poorly- or un-differentiated tumor, while $38.51 \%$ had moderately differentiated tumor and $20.45 \%$ had well differentiated tumor at diagnosis. Most patients had ductal histology $(83.29 \%)$, followed by lobular histology (10.69\%). The mean tumor size was $21.98 \mathrm{~mm}$. On average 6.11 nodes were examined in total for each patient, where average number of positive nodes identified was 1.14. The proportion of Blacks was higher in the groups of ER negative (14.48\%), PR negative $(12.02 \%)$, and triple negative $(27.78 \%)$ than that in the positive groups. Black patients counted for $11.11 \%$ of patients who did receive any surgery, $10.22 \%$ of patients who received mastectomy, $7.51 \%$ of patients who had other surgery, and $13.24 \%$ of patients with unknown surgery status. The proportion of Blacks was higher among patients who received chemotherapy (12.58\%) than among patients who did not receive chemotherapy $(7.22 \%)$. The percentage of Black patients was the highest among patients with distant diagnosis stage (18.84\%) and the lowest among patients with localized stage (7.14\%) among patients by cancer stage at diagnosis.
Among patients by cancer grades, the proportion of Blacks was the highest (13.18\%) among patients with poorlyor un-differentiated tumor, and was the lowest (4.67\%) among patients with well-differentiated tumor. Among groups by histology, the proportion of Blacks was the highest among patients with other histology (12.75\%), followed by $9.21 \%$ among patients who had ductal histology and $6.00 \%$ for patients with lobular histology. In addition, compared to non-Black patients, Black patients on average had larger tumor size, more positive nodes identified, and more nodes examined in total.

The Kaplan Meier survival curves for Black and nonBlack patients are shown in Figure 1. The Log-rank test indicates survival functions for Black and non-Black patients were significantly different over time, with a $\mathrm{p}$ value of less than 0.0001 . Figure 1 suggests survival probability for Blacks was always lower than that of non-Blacks after diagnosis.

The results of multivariate survival analysis from the time of diagnosis to death from breast cancer are shown in Table 3 below. The hazard of breast cancer death for women diagnosed with triple negative breast cancer and those with unknown triple negative status during study period were 4.34 and 2.35 times that of non-triple negative women, respectively. Death rate was 1.6 times for Blacks compared to that for nonBlacks over time.

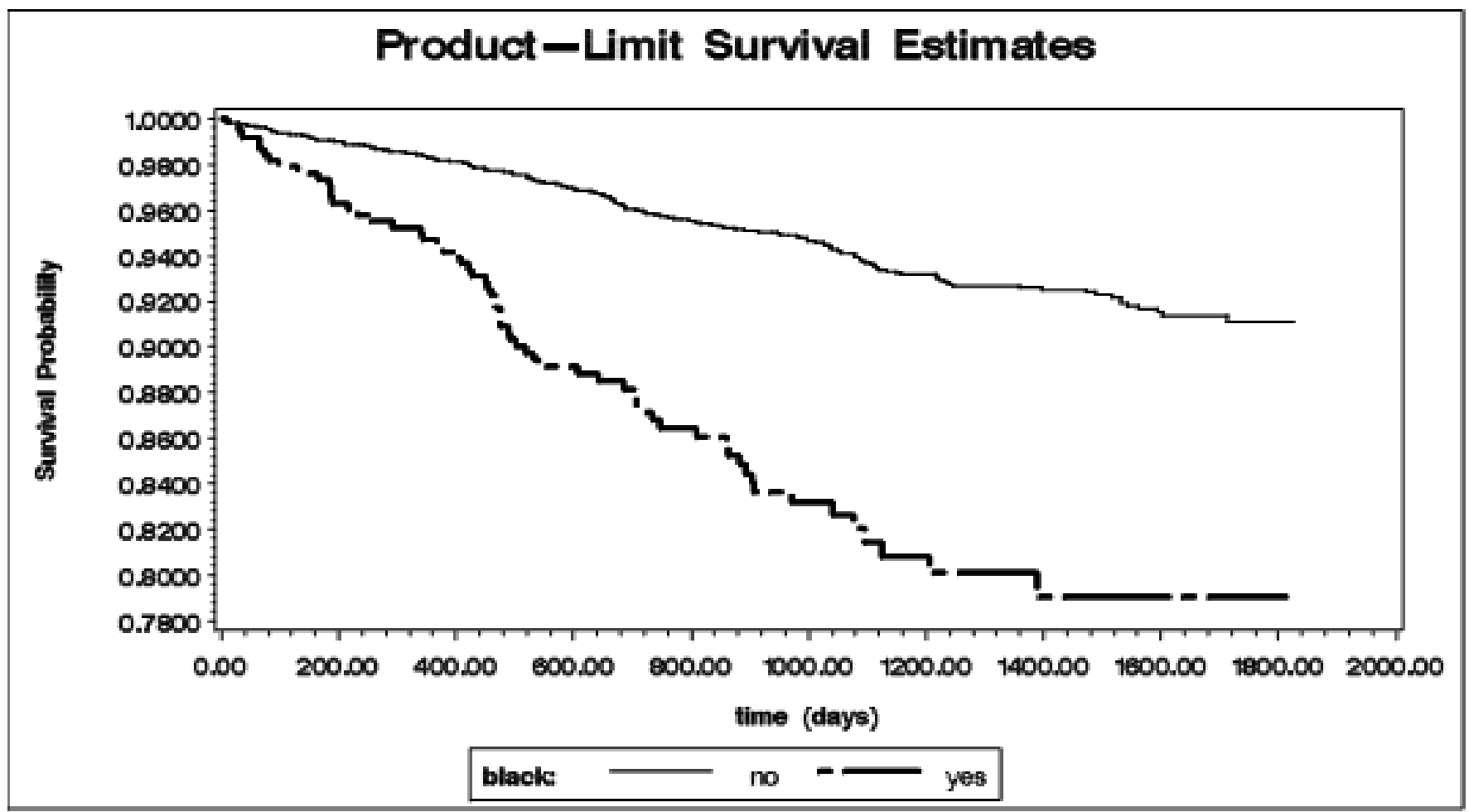


Table 3: multivariate survival analysis of time to breast cancer death $(\mathrm{N}=4,124)$

\begin{tabular}{|c|c|c|c|c|c|}
\hline Variable & & Estimate & Std. Err. & $\mathrm{p}$-value & Hazard Ratio \\
\hline \multirow[t]{2}{*}{ Triple Negative } & $\begin{array}{l}\text { Triple negative vs } \\
\text { Non-triple negative }\end{array}$ & 1.47 & 0.32 & $<.0001$ & 4.34 \\
\hline & $\begin{array}{l}\text { Unknown vs Non- } \\
\text { triple negative }\end{array}$ & 0.86 & 0.13 & $<.0001$ & 2.35 \\
\hline Comorbidity & & 0.47 & 0.13 & 0.0003 & $1.59^{*}$ \\
\hline Race & Black vs Non-Black & 0.46 & 0.16 & 0.0030 & 1.59 \\
\hline \multirow[t]{3}{*}{ Diagnosis stage } & $\begin{array}{l}\text { Distant vs Local- } \\
\text { ized stage }\end{array}$ & 4.93 & 0.98 & $<.0001$ & $138.95^{\star}$ \\
\hline & $\begin{array}{l}\text { Regional vs Local- } \\
\text { ized stage }\end{array}$ & 1.08 & 0.20 & $<.0001$ & 2.96 \\
\hline & $\begin{array}{l}\text { Unknown vs Local- } \\
\text { ized stage }\end{array}$ & 1.70 & 0.25 & $<.0001$ & 5.46 \\
\hline \multirow[t]{2}{*}{ Tumor grade } & $\begin{array}{l}\text { Moderately-vs } \\
\text { Well-differentiated }\end{array}$ & 0.61 & 0.32 & 0.0532 & 1.85 \\
\hline & $\begin{array}{l}\text { Poorly-/un-vs } \\
\text { Well-differentiated }\end{array}$ & 0.91 & 0.31 & 0.0034 & 2.49 \\
\hline Tumor size (mm) & & 0.01 & 0.00 & $<.0001$ & 1.01 \\
\hline Number of + nodes & & 0.10 & 0.02 & $<.0001$ & 1.10 \\
\hline Number of nodes & & -0.22 & 0.08 & 0.0054 & $0.81^{\star}$ \\
\hline \multirow[t]{3}{*}{ Breast surgery } & $\begin{array}{l}\text { Mastectomy vs No } \\
\text { surgery }\end{array}$ & 0.06 & 0.32 & 0.8539 & 1.06 \\
\hline & $\begin{array}{l}\text { Other surgery vs } \\
\text { No surgery }\end{array}$ & -0.27 & 0.34 & 0.4333 & 0.77 \\
\hline & $\begin{array}{l}\text { Unknown vs No } \\
\text { surgery }\end{array}$ & 0.49 & 0.30 & 0.1041 & 1.64 \\
\hline \multirow[t]{3}{*}{ Insurance } & $\begin{array}{l}\text { No insurance vs } \\
\text { Other insurance }\end{array}$ & 0.49 & 0.26 & 0.0619 & 1.63 \\
\hline & $\begin{array}{l}\text { Medicaid vs Other } \\
\text { insurance }\end{array}$ & 0.34 & 0.19 & 0.0729 & 1.41 \\
\hline & $\begin{array}{l}\text { Medicare vs Other } \\
\text { insurance }\end{array}$ & 0.50 & 0.14 & 0.0004 & 1.66 \\
\hline \multirow[t]{2}{*}{ Marital status } & $\begin{array}{l}\text { Unmarried vs Mar- } \\
\text { ried }\end{array}$ & 0.32 & 0.13 & 0.0150 & 1.37 \\
\hline & $\begin{array}{l}\text { Unknown vs Mar- } \\
\text { ried }\end{array}$ & -0.80 & 0.60 & 0.1800 & 0.45 \\
\hline \multicolumn{6}{|l|}{$\begin{array}{l}\text { Interactions with } \\
\text { time }\end{array}$} \\
\hline $\begin{array}{l}\text { Comorbidity } \quad x \\
\ln (\text { time })\end{array}$ & & -0.06 & 0.02 & 0.0051 & \\
\hline $\begin{array}{lll}\text { Distant } & \text { stage } & x \\
\ln (\text { time }) & & \\
\end{array}$ & & -0.41 & 0.16 & 0.0095 & \\
\hline $\begin{array}{l}\text { Number of nodes } x \\
\ln \text { (time) }\end{array}$ & & 0.03 & 0.01 & 0.0288 & \\
\hline
\end{tabular}

${ }^{\star} \mathrm{HR}$ at day 1 after diagnosis 
Other identified factors associated with an increased hazard over time were being diagnosed in regional stage or having unknown diagnosis stage, having moderately-, poorlyor un-differentiated tumor, being a Medicare recipient, being unmarried, with larger tumor size, and with more positive nodes detected. There were also factors whose effects changed over time. Diagnosis of distant stage was associated with a dramatically elevated risk of breast cancer death immediately after diagnosis compared to diagnosis of localized stage. Right after diagnosis, more comorbidity conditions were associated with higher hazard of breast cancer death. In addition, having more nodes examined in total was associated with a reduced risk of breast cancer death closely after diagnosis. However, interactions with time suggest the adverse effects of diagnosis of distant stage and more comorbidity conditions, as well as the positive effect of more nodes examined in total, were greatest instantly after diagnosis, then gradually attenuated over time.

\section{Discussion}

This study investigated the impact of triple negative phenotype on survival of patients with breast cancer using Florida statewide cancer registry data linked with hospital EMR data. The key findings were that women with TNBC had poorer survival compared to non-TNBC patients. Black women had worse BC survival compared to non-Black women. Distant stage at diagnosis was associated with the worst survival. Medicare recipients had the worst survival outcome compared with patients with other insurance. Married women had a better outcomes across the board compared to unmarried women. Having more nodes examined was associated with a reduced risk of $\mathrm{BC}$ death closely after diagnosis.

Our results confirmed the findings of previous studies and revealed that survival outcome in women with TNBC is significantly poorer compared to that of women with nonTNBC of breast cancer [10-12]. TNBC is potentially clinically relevant, as they differ in their underlying biology and clinical outcome and, consequently, requires different treatment strategies $[3,13]$. TNBC is more likely to spread to other organs and recur. This touches on the broader issue of developing strategies for identifying high-risk populations, including younger women, Black women, and breast cancer genes 1 mutation carriers. There is also a concerted effort to achieve improvement in survival in women with TNBC with implication for both clinical practice and clinical trial design $[14,15]$. These efforts have been directed towards developing new locoregional and systemic treatment strategies for patients with this aggressive subtype [16-18].

Our findings of poorer TNBC survival in Black women compared to non-Black women are in lines with those of other investigations $[12,19]$. Previous studies have also shown that racial disparity in TNBC survival persists even after adjustment for variables such as age, stage, socioeconomic status, insurance status, and, in some studies, pathologic characteristics $[7,19,20]$.
Factors that contribute to the Black-White disparities in TNBC survival may include differences in early detection and treatment. Black women have historically been less likely than Whites to be screened for breast cancer. Additionally, among Black women who undergo screening, delay in the timing of treatment initiation remains a consequence for increased recurrence and lower survival [21-23].

Our observation that distant stage at diagnosis was associated with the worst survival is similar across all malignancies. In fact, the extent of disease at diagnosis is the most important prognostic factor for cancer patients' survival. In fact, a study using the population-based California Cancer Registry data found that regardless of stage at diagnosis, women with TNBC had poorer survival than those with other breast cancers [12]. Previous findings indicate that women with TNBC tended to be diagnosed at advanced stage than those with nonTNBC $[12,24,25]$. When it comes to TNBC, disparity in stage at diagnosis may not totally be a consequence of socioeconomic factors such as low educational attainment, living in poverty, and lack of health insurance. Disparity in stage at diagnosis may partly be explainable by inherent biological differences. Research to determine whether there is a genetic component to the often aggressive and have a poorer prognosis in TNBC and race/ethnicity is ongoing. Nonetheless, thus far, the most consistent findings reveal specific genetic alterations that appears to impact prognosis factors, and treatment among Black women, ultimately contributing to survival rates [26-28]. The genetic risk factors that predispose Black women to TNBC is observed irrespectively of tumor size, stage, grade, presence of axillary lymph node metastasis, and age. Our findings show that Medicare recipients had worst survival. The poor health outcome in Medicare recipients could be explained by diagnosis at old age, comorbid conditions that are commonly present in elderly patients, and the non-receipt of standard therapy $[29,30]$. The diagnosis of cancer in the Medicare population, is often made amidst the diagnosis or treatment of other medical conditions. Comorbidity is a determinant of treatment selection, and adversely affects breast cancer survival [31-33]. Elderly patients with comorbidity do not receive standard cancer therapy because aging often involves a decline in tumor aggressiveness and a corresponding decline in the effectiveness of treatment such as chemotherapy [34-36]. The chance of completing the course of treatment is also lower among these patients [37]. Large randomized trials usually exclude elderly patients with breast cancer, as well as people with comorbidities, thus there is an insufficient evidence for the treatment of such patients [38-41].

Marital status has been associated with outcomes in several cancer sites [42-44]. The potentially significant impact that social support can have on breast cancer detection, treatment, and survival has been well described [45-47]. Married women are also more likely to participate in breast cancer screening compared to their unmarried counterparts [48-50]. 
Married women receive more spousal support and more likely than the unmarried to consult a healthcare provider at occurrence of symptoms, thus possibly detecting tumors at an earlier stage. After diagnosis with breast cancer, differences in receipt of treatments and adherence to treatment are paramount, with married women having a higher probability of complementing their course of treatment compared to those that are not married [51,52]. Married women are also more likely to have access to emotional support, financial support, physical care, and practical help, such as transportation to medical appointments or assistance [52]. Limitations of this study include the challenges that are inherent in using a cancer registry as a source of data. There were patients excluded because of missing information including cancer stage and receptor status. The data source also lacks other useful individual-level and area-level characteristics such as family history, lifestyle and environmental factors. In spite of these limitations, our results lend insight into the source of disparities and prognostic factors for TNBC survival. Most previous studies investigating breast cancer survival have been hampered by a lack of inclusion of women from Hispanic ethnic groups, a fast-growing population, a lack of information on ER/PR/HER2 status, and inconsistent assessment of other key factors such as treatment, socioeconomic status, body, and comorbid conditions. By linking the statewide cancer registry data with hospital EMR, we were able capture cancer diagnosis and treatment data more quickly and flexibly than was possible with traditional methods of cancer reporting, and the expanded data capacity provided invaluable potential for comparative effectiveness research on cancer treatments. Specifically, this study took advantage of patient data including detailed treatment. The linked dataset also allowed the investigators to obtain more in-depth information on a subtype of breast cancer than has been available in past studies. A key strength of the study is large sample size of 4,220 women diagnosed with breast cancer in Florida, during 2007-2010, with complete follow-up for vital status and causes of death.

\section{Conclusion}

This study is one of the first to use a comprehensive dataset to investigate survival in women with TNBC using a state population-based cancer registry. The study highlights the usefulness of EMRs in relation to cancer registries. Our findings indicate that despite the progress that has been made towards cancer prevention and control, not all segments of the population have benefitted equally from improvements in breast cancer. Women with triple negative breast cancer deserve special attention in clinical practice because of the uniqueness of this population. Future studies should examine the role of other factors that were not included in the present study, including the quality of care and particularly the benefit of treatment. There is an urgent need for clinicians, patients, researchers, and regulatory agencies to work together to facilitate research in triple-negative breast cancer populations.

\section{Acknowledgments}

This project was supported by grant number R24HS019658 from the Agency for Healthcare Research and Quality.

\section{References}

1) American Cancer society (2016) Breast Cancer Facts and Figures 2015 - 2016.

2) Andre F, Zielinski CC (2012) Optimal strategies for the treatment of metastatic triple-negative breast cancer with currently approved agents. Ann. Oncol $23: 46-51$

3) Cleator S, Heller W, Coombes RC (2007) Triple-negative breast cancer: therapeutic options. The lancet oncology 8: 235-244

4) Amirikia KC, Mills P, Bush J, Newman LA (2011) Higher population-based incidence rates of triple-negative breast cancer among young African-American women : Implications for breast cancer screening recommendations 117: 2747-2753.

5) Dietze EC, Sistrunk C, Miranda-Carboni G, O’Regan R, Seewaldt VL (2015) Triple-negative breast cancer in African-American women: disparities versus biology. Nat Rev Cancer 15 : 248-254.

6) Chu QD, Henderson AE, Ampil F, Li BD (2012) Outcome for patients with triple-negative breast cancer is not dependent on race/ ethnicity. Int J Breast Cancer 2012:764570.

7) Lin NU, Vanderplas A, Hughes ME et al. (2012) Clinicopathologic features, patterns of recurrence, and survival among women with triple-negative breast cancer in the National Comprehensive Cancer Network. Cancer 118: 5463-5472.

8) Pacheco JM, Gao F, Bumb C, Ellis MJ, Ma CX (2013) Racial differences in outcomes of triple-negative breast cancer. Breast Cancer Res Treat 13: 281-289.

9) Huang Y (2013) Expansion Research Capability to Study Comparative Effectiveness in Complex Patients.

10) Onitilo AA, Engel JM, Greenlee RT, Mukesh BN (2009) Breast cancer subtypes based on ER/PR and Her2 expression: comparison of clinicopathologic features and survival. Clin Med Res 7: 4-13.

11) Nishimura R, Arima N (2008) Is triple negative a prognostic factor in breast cancer? Breast Cancer. 15: 303-308 .

12) Bauer KR, Brown M, Cress RD, Parise CA, Caggiano V (2007) Descriptive analysis of estrogen receptor (ER)-negative, progesterone receptor (PR)-negative, and HER2-negative invasive breast cancer, the so-called triple-negative phenotype. Cancer. 109: 1721-1728 .

13) Schneider BP, Winer EP, Foulkes WD et al. (2008) Triple-negative breast cancer: risk factors to potential targets. Clin Cancer Res 14: 8010-8018.

14) Narod SA, Dent RA, Foulkes WD (2015) CCR 20th Anniversary Commentary: Triple-Negative Breast Cancer in 2015-Still in the Ballpark. Foulkes WD. Clin. Cancer Res. 21: 3813-3814.

15) Zhang L, Fang C, Xu X, Li A, Cai Q, et al.(2015) Androgen receptor, EGFR, and BRCA1 as biomarkers in triple-negative breast cancer: a meta-analysis. BioMed research international 2015: 357485.

16) Cameron D, Brown J, Dent R, Jackisch C, Mackey J, Pivot X, et al. (2013) Adjuvant bevacizumab-containing therapy in triple-negative breast cancer (BEATRICE): primary results of a randomised, phase 3 trial. The lancet oncology. 14: 933-942.

17) Zumsteg ZS, Morrow M, Arnold B et al. (2013) Breast-conserving therapy achieves locoregional outcomes comparable to mastectomy in women with T1-2N0 triple-negative breast cancer. Annals of surgical oncology 20: 3469-3476. 
18) Mayer IA, Abramson VG, Lehmann BD, Pietenpol JA. (2014) New strategies for triple-negative breast cancer--deciphering the heterogeneity. Clin. Cancer Res 20: 782-790.

19) Lund MJ, Trivers KF, Porter PL et al. (2009) Race and triple negative threats to breast cancer survival: a population-based study in Atlanta, GA. Breast Cancer Res. Treat. 113(2), 357-370 .

20) Sprague BL, Trentham-Dietz A, Gangnon RE et al. Socioeconomic status and survival after an invasive breast cancer diagnosis. Cancer $117: 1542-1551$.

21) Bustami RT, Shulkin DB, O’Donnell N, Whitman ED (2014) Variations in time to receiving first surgical treatment for breast cancer as a function of racial/ethnic background: a cohort study. JRSM Open. 5: 2042533313515863 .

22) Gagliato Dde M, Gonzalez-Angulo AM, Lei X et al. (2014) Clinical impact of delaying initiation of adjuvant chemotherapy in patients with breast cancer. J. Clin. Oncol 32: 735-744.

23) Smith EC, Ziogas A, Anton-Culver H (2013) Delay in surgical treatment and survival after breast cancer diagnosis in young women by race/ethnicity. JAMA surgery 148: 516-523.

24) Zhu W, Perez EA, Hong R, Li Q, Xu B. Age-related disparity in immediate prognosis of patients with triple-negative breast cancer: a population-based study from SEER cancer registries. PloS one 10: e0128345.

25) Lee E, McKean-Cowdin R, Ma H et al. (2011) Characteristics of triple-negative breast cancer in patients with a BRCA1 mutation: results from a population-based study of young women. J. Clin. Oncol. 29: 4373-4380.

26) Keenan T, Moy B, Mroz EA, Ross K, Niemierko A et al. ( 2015) Comparison of the Genomic Landscape Between Primary Breast Cancer in African American Versus White Women and the Association of Racial Differences With Tumor Recurrence. J. Clin. Oncol. 33: 3621-3627.

27) Sullivan HC, Oprea-Ilies G, Adams AL et al. (2014) Triple-negative breast carcinoma in African American and Caucasian women: clinicopathology, immunomarkers, and outcome. Appl. Immunohistochem. Mol. Morphol. 22: 17-23.

28) Sturtz LA, Melley J, Mamula K, Shriver CD, Ellsworth RE (2014) Outcome disparities in African American women with triple negative breast cancer: a comparison of epidemiological and molecular factors between African American and Caucasian women with triple negative breast cancer. BMC Cancer. 14-62.

29) Patnaik JL, Byers T, Diguiseppi C, Denberg TD, Dabelea D (2011) The influence of comorbidities on overall survival among older women diagnosed with breast cancer. J. Natl. Cancer Inst. 103: 1101-1111 . 30) Schonberg MA, Marcantonio ER, Li D, Silliman RA, Ngo L, McCarthy EP (2010) Breast cancer among the oldest old: tumor characteristics, treatment choices, and survival. J. Clin Oncol 28: 2038-2045. 31 ) Berglund A, Wigertz A, Adolfsson J, Ahlgren J, Fornander T, et al. (2012) Impact of comorbidity on management and mortality in women diagnosed with breast cancer. Breast Cancer Res. Treat. 135: 281-289.

32) Griffiths RI, Gleeson ML, Valderas JM, Danese MD. (2014) Impact of undetected comorbidity on treatment and outcomes of breast cancer. Int. J. Breast Cancer 2014: 970780.

33) Sogaard M, Thomsen RW, Bossen KS, Sorensen H, Norgaard M (2013) The impact of comorbidity on cancer survival: a review. Clin Epidemiol 5:3-29.

34) Allemani C, Storm H, Voogd AC, Holli K, Izarzugaza I, et al. (2010) Variation in 'standard care'for breast cancer across Europe: a EUROCARE-3 high resolution study. Eur. J. Cancer 46: 1528-1536.
35) Giordano SH, Hortobagyi GN, Kau SW, Theriault RL, Bondy ML (2005). Breast cancer treatment guidelines in older women. J Clin Oncol 23: 783-791.

36) Eisinger F, Ronda I, Puig B, Camerlo J, Giovannini M, et al. (2007) Breast cancer guidelines-Physicians' intentions and behaviors. Int J Cancer 120: 1136-1140.

37) Owusu C, Buist DS, Field TS, Lash TL, Thwin SS et al. (2008) Predictors of tamoxifen discontinuation among older women with estrogen receptor-positive breast cancer. J Clin Oncol 26: 549-555.

38) Lewis JH, Kilgore ML, Goldman DP, Trimble EL, Kaplan R et al. (2003) Participation of patients 65 years of age or older in cancer clinical trials. J Clin Oncol 21: 1383-1389.

39) Kemeny MM, Peterson BL, Kornblith AB, Muss HB, Wheeler J, et al. (2003) Barriers to clinical trial participation by older women with breast cancer. J Clin Oncol 21: 2268-2275.

40) Boyd CM, Vollenweider D, Puhan MA (2012) Informing evidence-based decision-making for patients with comorbidity: availability of necessary information in clinical trials for chronic diseases. PloS one. 7: e41601.

41) Lind KD (2011) Excluding older, sicker patients from clinical trials: issues, concerns, and solutions. AARP Public Policy Institute.

42) Abdollah F, Sun M, Thuret R, Abdo A, Morgan M, et al. (2011) The effect of marital status on stage and survival of prostate cancer patients treated with radical prostatectomy: a population-based study. Cancer Causes \& Control 22: 1085-1095.

43) Kravdal H, Syse A (2011) Changes over time in the effect of marital status on cancer survival. BMC Public Health 11: 804.

44) Goffredo P, Sosa JA, Roman SA (2013) Differentiated thyroid cancer presenting with distant metastases: a population analysis over two decades. World J. Surg. 37: 1599-1605.

45) Celaya MO, Berke EM, Onega TL, Gui J, Riddle BL, et al. (2010). Breast cancer stage at diagnosis and geographic access to mammography screening (New Hampshire, 1998-2004). Rural Remote Health 10: 1361.

46) Osborne C, Ostir GV, Du X, Peek MK, Goodwin JS (2005) The influence of marital status on the stage at diagnosis, treatment, and survival of older women with breast cancer. Breast Cancer Res. Treat. 93: 41-47.

47) Kroenke CH, Kubzansky LD, Schernhammer ES, Holmes MD, Kawachi I (2006) Social networks, social support, and survival after breast cancer diagnosis. J Clin Oncol 24: 1105-11

48) Madadi M, Zhang S, Yeary KHK, Henderson LM (2014) Analyzing factors associated with women's attitudes and behaviors toward screening mammography using design-based logistic regression. Breast Cancer Res. Treat. 144: 193-204.

49) Alford SH, Leadbetter S, Rodriguez JL, Hawkins NA, Scholl LE, et al.(2015) Cancer screening among a population-based sample of insured women. Preventive medicine reports. 2:15-20.

50) Patel K, Kanu M, Liu J, Bond B, Brown E, et al. (2014) Factors influencing breast cancer screening in low-income African Americans in Tennessee. J Community Health 39: 943-950.

51) Aizer AA, Chen MH, McCarthy EP, Mendu ML, Koo S, et al. (2013) Marital status and survival in patients with cancer. J Clin Oncol 31: 3869-3876.

52) DiMatteo MR (2004) Social support and patient adherence to medical treatment: a meta-analysis. Health psychology. 23: 207-218. 
Submit your manuscript to a JScholar journal and benefit from:

- Convenient online submission

I Rigorous peer review

- Immediate publication on acceptance

- Open access: articles freely available online

I High visibility within the field

q Better discount for your subsequent articles

Submit your manuscript at http://www.jscholaronline.org/submit-manuscript.php 